\title{
COMPETITIVIDADE DAS EXPORTAÇÕES BRASILEIRAS E INDONÉSIAS DE CAFÉ ${ }^{1}$
}

\author{
Leonardo Sangoi Copetti ${ }^{2}$ \\ Daniel Arruda Coronel ${ }^{3}$
}

\begin{abstract}
Resumo: $O$ objetivo deste estudo foi o de analisar a competitividade das exportações brasileiras no mercado mundial do café, entre 2000 a 2016, em comparação ao quarto maior produtor e exportador mundial, a Indonésia. Os dados foram coletados no site do UN COMTRADE (United Nations Comtrade), da FAO (Food and Agriculture Organization of the United Nations) e da WTO (World Trade Organization). A metodologia empregada baseou-se no Índice de Vantagem Comparativa Revelada Simétrica (VCRS), na Razão de Concentração (CR), e no Índice de Orientação Regional (IOR). Os resultados revelaram que tanto o Brasil quanto a Indonésia apresentaram vantagens comparativas para as exportações de café. Em relação à CR, o Brasil apresentou concentração e a Indonésia desconcentração das exportações. O IOR indicou orientação das exportações de café do Brasil para Alemanha, Itália e Estados Unidos. Já o IOR da Indonésia apresentou orientação das exportações de café somente aos Estados Unidos e à Alemanha.
\end{abstract}

Palavras-Chave: Café. Competitividade. Comércio Internacional.

\section{COMPETITIVENESS OF BRAZILIAN AND INDONESIAN COFFEE EXPORTS}

\begin{abstract}
The objective of this study was to analyze the competitiveness of Brazilian exports in the global trade of coffee, between 2000 and 2016, in comparison to the fourth global producer and exporter, Indonesia. The data were collected in the UN COMTRADE (United Nations Comtrade), FAO (Food and Agriculture Organization of the United Nations) and WTO (World Trade Organization)sites. The methodology used was based on Revealed Symmetric Comparative Advantage Index (RCA), onConcentration Ratio (CR), and on Regional Orientation Index (ROI). The results revealed that both Brazil and Indonesia presented comparative advantages for the coffee exports. In relation to $C R$, Brazil presented concentration and Indonesia deconcentration of exports. The ROI indicated orientation of coffee exports from Brazil to Germany, Italy and the United States. Yet, the ROI of Indonesia presented orientation of coffee exports only to the United States and to Germany.
\end{abstract}

Keywords: Coffee; Competitiveness; International Trade.

\section{Introdução}

O comércio mundial cresceu $181 \%$ em exportações ligadas ao agronegócio, entre os anos de 2000 a 2016, passando de US\$ 558 bilhões a US\$1,57 trilhões, respectivamente, segundo a World Trade Organization (WTO, 2017). Além disso, a participação do setor sobre o total exportado mundial teve aumento de 1 ponto percentual, sendo que, em 2000, era de $9 \%$ e, em 2016, passou a 10\%. Segundo Vieira Filho \& Fishow (2017), esse período, a partir da década de 2000, foi caracterizado como o "boom das commodities", sendo impulsionado pelo acelerado volume de exportações agropecuárias mundiais e influenciadas pela alta demanda dos produtos de origem primária nos países emergentes, com a modernização tecnológica e a concorrência entre os demais exportadores (VIEIRA FILHO; FISHLOW, 2017).

\footnotetext{
${ }^{1}$ Este artigo faz parte de uma pesquisa, a qual visa estudar a competitividade das exportações brasileiras no mercado do café e conta com o apoio do CNPq, através da chamada Universal-2018.

${ }^{2}$ Mestre em Administração pela Universidade Federal de Santa Maria (UFSM).

3 Doutor em Economia Aplicada pela Universidade Federal de Viçosa (UFV), Professor Associado do Departamento de Economia e Relações Internacionais.
} 
Neste contexto, segundo a World Trade Organization (WTO, 2018), o Brasil teve um incremento de quase $400 \%$ no faturamento das exportações ligadas ao agronegócio que, nos anos 2000, eram de US\$ 15,5 bilhões e passaram para US\$ 6 bilhões em 2016. Já a participação do setor sobre o total exportado pelo país teve aumento de 13,48 pontos percentuais, sendo que, em 2000 , era de $28,06 \%$ e, em 2016 , de $41,54 \%$.

Além disso, conforme dados da Food and Agriculture Organization of the United Nations - (FAO, 2018), o Brasil é o maior exportador mundial de café, uma vez que, em 2016, o valor exportado foi de US\$ 4,84 bilhões, o que representou 2,61\% das exportações deste país, e $25 \%$ das exportações mundiais. Em comparação com ano 2000, o crescimento das exportações brasileiras de café foi de $210 \%$, e, neste ano, eram de US\$1,56 bilhões.

Já na Indonésia, a participação do agronegócio no total exportado aumentou cerca de $15 \%$, sendo que, em 2000, era de 12\%, e, em 2016, de 27\% (WTO, 2018). Além disso, o crescimento nas exportações de café neste período foi de $221 \%$, passando de US\$ 312 milhões nos anos 2000 para US\$ 1 bilhão em 2016, representando 0,68\% das exportações do país e 6\% das exportações mundiais (UN COMTRADE, 2018).

Para a FAO (2018), os três maiores importadores mundiais de café verde, em 2016, foram, respectivamente, Estados Unidos, com 1,52 milhões de toneladas (21,07\%), Alemanha com 1,14 milhões de toneladas (15,84\%) e Itália com 580 mil toneladas. Além disso, segundo a Word Trade Organization - WTO (2019), dentre esses três maiores importadores, Alemanha e Itália aplicam um percentual médio de tarifas de importação de 9,08\%, e os Estados Unidos não aplicam taxas de importação à commodity.

Neste sentido, o presente estudo tem o seguinte problema de pesquisa: "Brasil e Indonésia foram competitivos no mercado mundial do café entre 2000 e 2016?” Para responder ao questionamento, o objetivo do trabalho foi o de analisar a competitividade das exportações brasileiras e indonésias no mercado mundial do café, entre 2000 a 2016, uma vez que o Brasil é o maior produtor e exportador, e a Indonésia é o quarto maior produtor e exportador de café mundial.

A metodologia empregada na pesquisa baseou-se no Índice de Vantagem Comparativa Revelada Simétrica (VCRS), na Razão de Concentração (CR), e no Índice de Orientação Regional (IOR). O ineditismo desta pesquisa está relacionado à análise do mercado do café internacional, traçando um comparativo entre Brasil e Indonésia que, juntos, destinaram ao mercado externo mais de US\$ 5,84 bilhões, em 2016, de café verde, representando $31 \%$ do faturamento total mundial na exportação desta commodity (UN COMTRADE, 2018). Além disso, as exportações do café verde representam uma parcela do comércio mundial de café, 
correspondente a $52 \%$, que também é composto por produtos, tais como os extratos de café e o café torrado, que, em conjunto com o café verde, totalizou mais de US\$ 37,15 bilhões em exportação em 2016 (FAO, 2018). Desta forma, esta pesquisa pode servir de subsídio para ações visando fomentar a competitividade do setor, tais como esforço de liberalização multilateral que exclua a redução de barreiras comerciais no agronegócio entre os países, participação de acordos preferenciais de comércio e políticas setoriais de apoio à agricultura (GURGEL, 2014).

Com o intuito de atingir o objetivo do trabalho de avaliar a competitividade das exportações brasileiras no mercado mundial do café, entre 2000 a 2016, em comparação com a Indonésia, este estudo está organizado em mais quatro seções, além desta introdução. Na segunda seção, apresentam-se o conceito de competitividade e os estudos empíricos realizados sobre a exportação e a competitividade do café brasileiro, e por fim o panorama do comércio internacional do café, destacando o Brasil e a Indonésia. A terceira seção compreende os procedimentos metodológicos. Na quarta seção, os resultados são discutidos e analisados. Por fim, na quinta seção, são expostas as conclusões do estudo.

\section{Competitividade no Mercado Mundial do Café}

\subsection{Competitividade}

A competitividade, segundo Ricardo (1996), economista inglês do século XIX, relacionase às Vantagens Comparativas que um país possui em relação a outro, pela qual a abundância de recursos naturais favoreceria o competidor que os tivesse. Também se refere a outros fatores como a escala de produção, a existência de capital físico (equipamentos, infraestrutura, vias, portos, etc) e humano (investimentos destinados à formação educacional e profissional de uma determinada população), e abertura econômica.

Ricardo (1996) explica a teoria utilizando como referência Inglaterra e Portugal e os produtos tecidos e vinhos. Se Portugal ou Inglaterra não tivessem nenhuma ligação comercial entre si e produzissem os dois produtos, seriam obrigados a aplicar todos os seus recursos na produção destes e, com isso, os resultados seriam provavelmente inferiores em quantidade e qualidade. Já o comércio faria com que os países se beneficiassem com a especialização e produção do produto em que possuem maior vantagem e com a importação do outro.

No exemplo citado por Ricardo (1996), a Inglaterra produziria tecidos e vinhos utilizando, respectivamente, 100 e 120 homens por ano e Portugal 90 e 80. Da situação analisada no todo se deduziria que a produção deveria ocorrer exclusivamente em Portugal, já que o custo na produção de ambos os produtos é menor, contudo, examinando o cenário à luz das vantagens comparativas, percebe-se que, se a Inglaterra se especializasse em tecidos e Portugal em vinhos, 
ambos obteriam maiores ganhos na produção e na troca comercial. Neste caso, o preço relativo de cada produto seria de $0,83(100 / 120)$ para o tecido na Inglaterra; $1,20(120 / 100)$ para o vinho na Inglaterra; 1,125 (90/80) para o tecido em Portugal; e 0,88 (80/90) para o vinho em Portugal. Ou seja, o aperfeiçoamento na produção do produto em que cada país possui maior vantagem comparativa e a troca pelo outro proporcionaria maiores ganhos para ambos.

Não obstante a isso, segundo Porter (1988), a competitividade também estaria relacionada à produtividade que determinado país possui no processo de fabricação de um produto, que, para Ricardo, era explicada pelos custos de produção e pela vantagem comparativa. Tendo em vista este posicionamento, é possível elucidar o porquê de certos países como a Alemanha, a Suíça e a Suécia, onde os salários são altos e a mão de obra não é tão abundante, prosperam e serem altamente competitivos.

Ainda, para Porter (1988), a vantagem competitiva de uma nação relaciona-se a quatro determinantes, a saber:

1. Condições de fatores: a posição do país nos fatores de produção, como trabalho especializado, infraestrutura, necessários à competição em determinada indústria;

2. Condições de demanda: como a demanda interna de um país se manifesta voltada aos produtos ou serviços da indústria, este determinante é relevante na medida em que promove a melhoria e inovação pelas empresas do país e reflete o grau de exigência que o mercado tem pela qualidade dos produtos;

3. Indústrias correlatas e de apoio: referem-se às indústrias produtoras do maquinário necessário à produção de determinado produto; e

4. Estratégia, estrutura e rivalidade das empresas: as condições e políticas da nação onde se está produzindo determinado produto. $\mathrm{O}$ autor cita do caso de Londres, na Inglaterra, que teve seu desenvolvimento relacionado à sua demanda avançada de muitos bens e serviços, à concentração industrial e à presença maciça de mão de obra altamente especializada.

Para Best (1990), uma organização de negócios é competitiva quando integra o pensar e o fazer através da procura continuada de melhoria. Como forma de elucidar seu pensamento, o autor cita o exemplo de duas regiões produtoras de armas leves para infantaria, uma em Birmingham, na Inglaterra, e outra nos Estados Unidos, em Conecticut, chamada de Springfield Armory. Nos Estados Unidos, a produção era bem desenvolvida, com sistemas automatizados em torno e forja. Já na Inglaterra, o processo produtivo se dava de forma manual e artesanal. Como resultado, a indústria americana desenvolveu-se e tornou-se produtiva, e a inglesa tornou-se decadente e entrou em recessão. 
Ainda nesta perspectiva, Best (1990) conclui que a mudança nos sistemas de produção relacionase às grandes mudanças tecnológicas ocorridas nos Estados Unidos, que possibilitaram a introdução de novas tecnologias de produção e, consequentemente, promoveram seu desenvolvimento e prosperidade.

Além disso, a definição do conceito de competitividade relaciona-se diretamente à escolha dos indicadores de desempenho a serem utilizados. Como exemplo, cita-se a evolução da participação de mercado, que pode sintetizar muito fatores competitivos de um concorrente (KENNEDY et al., 1998).

Fatores como custos, produtividade, inovação em produto e processo também são frequentemente utilizados como forma de comparar e medir a competitividade. Esses fatores, se somados, apresentam-se como determinantes da preservação e melhoria das participações de mercado (KENNEDY et al., 1998).

É importante ressaltar que a evolução da participação de mercado refere-se a um fator no passado, associado às vantagens competitivas já adquiridas. Também se relaciona à adequação da empresa ou nação no setor que esteja concorrendo (KENNEDY et al., 1998).

Nesta subseção, foram apresentados conceitos sobre a competitividade que embasaram a presente pesquisa. Na subseção seguinte, apresentam-se estudos empíricos sobre a competitividade brasileira no mercado do café.

\subsection{Estudos empíricos acerca das exportações e da competitividade brasileira na comercialização do café}

Sereia, Camara \& Anhesini (2012) analisaram o comportamento de indicadores de comércio exterior do complexo cafeeiro brasileiro entre 1990 e 2007. Para tanto, foram utilizados o modelo Constant Market Share (CMS) com os produtos café verde, café solúvel, café torrado e bebidas com café, bem como o índice de Vantagem Comparativa Revelada Simétrica (VCRS). A aplicação do modelo CMS permitiu analisar a decomposição e a contribuição das fontes de crescimento das exportações em três períodos considerados: período I (1990-1993 no comparativo com 1994-1998), período II (1994-1998 no comparativo com 19992003), e período III (1999-2003 no comparativo com 2004-2007). O modelo CMS permitiu identificar quatro determinantes, a saber: a) o efeito crescimento do comércio internacional; b) o efeito composição da pauta de exportações; c) o efeito destino das exportações; e d) o efeito competitividade, determinado pelo resíduo das demais. Como resultados do modelo CMS, na análise dos quatro produtos em conjunto (café verde, solúvel, torrado e bebidas com café), temse que o desempenho das exportações brasileiras é atribuído aos efeitos de crescimento do 
comércio mundial e, principalmente, da competitividade, que apresentou resultados positivos durante todo período, oscilando entre $51,1 \%$ a $222,2 \%$. O mesmo resultado do CMS ocorreu na análise dos produtos do café em separado, sendo o desempenho nas exportações relacionado aos efeitos crescimento mundial e ao efeito competitividade que variou, para o café verde, o café solúvel, o café torrado e as bebidas com café, respectivamente, de 51,1\% a 226,2\%, de 38,3\% a $178,3 \%$, de $56,6 \%$ a $122,9 \%$, e de $54,8 \%$ a $149,2 \%$. Para o VCRS, as exportações brasileiras de café apresentam-se competitivas com índice variando, para os produtos café verde e café solúvel, respectivamente, de 0,89 a 0,93 , e de 0,81 a 0,92 . O produto café torrado não se apresentou competitivo durante o período de análise.

Thomé \& Ferreira (2015) realizaram pesquisa sobre a competitividade das exportações do café brasileiro no comparativo com seus principais concorrentes (Vietnã, Alemanha, Colômbia, Suíça, Honduras, Itália, Indonésia, Bélgica e Etiópia), no período de 2003 a 2012, e para tanto, utilizaram a seguinte metodologia: índices de Vantagem Comparativa Revelada (IVCR), Posição Relativa do Mercado (PRM), Índice de Herfindahl-Hirschman (IHH) para avaliar a concentração de mercado, e Índice de Exportação Líquida (NEI). Como resultados, o Brasil apresentou-se competitivo durante todo período de análise, com VCRs superiores à unidade, e com valores passando de 17,74 em 2003 a 12,73 em 2012, e chegando, em 2004, a 18,03. Em relação à PRM, o Brasil apresentou como resultado o valor de 8,57 em 2012, conferindo-lhe destaque no comércio internacional do café, seguido por Colômbia $(5,15)$ e Vietnã $(2,68)$. Já em relação ao IHH, apresentou como resultado mercado concentrado nas exportações mundiais de café, com valores passando de 42,62\%, em 2003, a 41,05,\% em 2012. O NEI revelou o perfil dos países exportadores: Itália e Bélgica, com valor do índice próximo a zero, região de neutralidade, indicando que estes países não apresentam características de produção doméstica, mas são estáveis em comércio (importação e exportação); Brasil, Vietnã, Colômbia, Honduras, Indonésia e Etiópia com valores próximos a 1, o que indica estabilidade na exportação com base na produção doméstica; e Alemanha e Suíça, com valores negativos e não próximos a zero e a -1, revelando a estabilidade na comercialização (importação e exportação), e com acentuado consumo doméstico.

Franck et al. (2016) investigaram a competitividade das exportações brasileiras de café utilizando os Índices de Orientação Regional (IOR) e de Vantagem Comparativa Revelada (IVCR), no período de 1999 a 2014. Os resultados indicaram que as exportações brasileiras de café foram orientadas durante todo período para a Alemanha, com IOR superior à unidade, e orientadas aos Estados Unidos somente a partir do ano de 2006. Em ambos os países, a tendência do IOR foi crescente, o que indica incremento das exportações do Brasil aos parceiros 
comerciais. Em relação ao IVCR, foi superior à unidade de 1999 a 2014, e com tendência decrescente, indicando a competitividade do país brasileiro no comércio mundial do café, e também redução desta no período de análise.

Arevalo, Arruda \& Carvalho (2016) utilizaram o modelo Constant Market Share (CMS) e o Índice de Vantagem Comparativa Revelada (IVCR) para analisar as exportações totais de café verde do Brasil, Colômbia e Peru, no período de 1994 a 2013. A aplicação do modelo CMS permitiu analisar a decomposição e a contribuição das fontes de crescimento das exportações do café em três períodos considerados: período I (1994-1998 no comparativo com 1999-2003), período II (1999-2003 no comparativo com 2004-2008), e período III (2004-2008 no comparativo com 2009-2013). O modelo CMS permitiu identificar três efeitos: a) crescimento das exportações no mundo; b) composição da pauta de exportações do país; e c) resíduo inexplicável ou "efeito competitividade". Como resultados, as exportações brasileiras de café foram competitivas durante todo o período de análise, com IVCR superior à unidade, variando entre 7,20 e 20,84. Além disso, o Brasil foi o mais competitivo em 1999, 2001, e de 2004 a 2011 , apresentando IVCRs superiores aos concorrentes. Em relação ao CMS, o Brasil ampliou seu market-share nos períodos I, II, e II, respectivamente, de $18,73 \%$ para $21,74 \%$, de $21,74 \%$ para $25,13 \%$, de $25,13 \%$ para $28,61 \%$, sendo que o efeito crescimento do mercado mundial foi determinante para explicar o incremento nas exportações de café do Brasil, dado que o valor percentual nos três períodos foi muito significativo. O efeito competitividade apresentou-se positivo nos períodos II e III, explicando parte do crescimento nas exportações brasileiras do café verde. Na Figura 1, faz-se uma síntese dos estudos acerca da competitividade do café.

Figura 1 - Síntese dos estudos empíricos

\begin{tabular}{|c|c|c|c|c|c|}
\hline Autores & Região & Período & Produtos & Metodologia & Resultados \\
\hline $\begin{array}{c}\text { Sereia, } \\
\text { Camara \& } \\
\text { Anhesini } \\
(2012)\end{array}$ & Brasil & $1990-$ & $\begin{array}{c}\text { Café (verde, } \\
\text { solúvel e } \\
\text { torrado) }\end{array}$ & CMS e VCRS. & $\begin{array}{c}\text { Brasil competitivo } \\
\text { no café verde e } \\
\text { solúvel de } 1990 \text { a } \\
2007 .\end{array}$ \\
\hline $\begin{array}{c}\text { Thomé \& } \\
\text { Ferreira } \\
(2015)\end{array}$ & $\begin{array}{c}\text { Brasil, Vietnã, } \\
\text { Alemanha, } \\
\text { Colômbia, Suíça, } \\
\text { Honduras, Itália, } \\
\text { Indonésia, Bélgica e } \\
\text { Etiópia }\end{array}$ & $2003-$ & Café & $\begin{array}{c}\text { IVCR, PRM, } \\
\text { IHH, e NEI. }\end{array}$ & $\begin{array}{c}\text { Brasil competitivo } \\
\text { de 2003 a 2012. }\end{array}$ \\
\hline $\begin{array}{c}\text { Franck et al. } \\
(2016)\end{array}$ & Brasil & $1999-$ & Café & IOR e IVCR. & $\begin{array}{c}\text { Brasil competitivo } \\
\text { de 1999 a 2014. }\end{array}$ \\
\hline $\begin{array}{c}\text { Arevalo, } \\
\text { Arruda \& }\end{array}$ & Brasil, Colômbia e & $1994-$ & Café verde & CMS e IVCR. & Brasil competitivo \\
Carvalho & Peru & 2013 & & & \\
$(2016)$ & & & & & \\
\hline
\end{tabular}

Fonte: Organização dos autores 
Nesta subseção, foram reunidos estudos realizados sobre o café brasileiro a fim de analisar as exportações e a competitividade do país na comercialização do produto, com base, principalmente, no IVCR e VCRS. Os estudos supracitados revelaram que o Brasil apresentou competitividade nas exportações de café de 1990 a 2014. Na subseção seguinte, apresenta-se o panorama do comércio internacional do café, com destaque para o Brasil e a Indonésia.

\subsection{Participação do Brasil e da Indonésia no mercado do café}

Segundo a Food and Agriculture Organization of the United Nations (FAO, 2018), o Brasil foi o maior produtor e exportador mundial de café, em 2016, quando o país produziu 3,02 milhões de toneladas do produto, representando $32,74 \%$ da produção mundial, que foi de 9,22 milhões de toneladas. Neste período, a Indonésia aparece em quarto lugar, com a produção de 0,64 milhões de toneladas. Do total produzido pelo mundo, cerca de 7,16 milhões de toneladas foram destinadas à exportação: o Brasil destinou 1,82 milhões de toneladas ao mercado externo, assumindo a primeira posição entre os maiores exportadores mundiais, e a Indonésia exportou 0,41 milhões de toneladas, sendo a quarta maior exportadora. A Tabela 1 ilustra as participações dos maiores produtores de café nos anos de 2000 e 2016.

Tabela 1 - Participação dos maiores produtores mundiais de café em 2000 e em 2016

\begin{tabular}{|c|c|c|c|c|c|}
\hline \multirow[b]{2}{*}{ País } & \multicolumn{2}{|c|}{2000} & \multicolumn{2}{|c|}{2016} & \multirow[b]{2}{*}{$\begin{array}{l}\text { Variação da } \\
\text { participação } \\
\text { (em p.p.) }\end{array}$} \\
\hline & $\begin{array}{c}\text { Produção } \\
\text { (milhões de } \\
\text { toneladas) }\end{array}$ & $\begin{array}{c}\text { Participação } \\
(\%)\end{array}$ & $\begin{array}{c}\text { Produção } \\
\text { (milhões de } \\
\text { toneladas) }\end{array}$ & $\begin{array}{c}\text { Participação } \\
(\%)\end{array}$ & \\
\hline Brasil & 1,90 & 25,37 & 3,02 & 32,74 & 7,37 \\
\hline Vietnã & 0,80 & 10,70 & 1,46 & 15,84 & 5,14 \\
\hline Colômbia & 0,64 & 8,49 & 0,75 & 8,08 & $-0,41$ \\
\hline Indonésia & 0,55 & 7,39 & 0,64 & 6,93 & $-0,46$ \\
\hline Etiópia & 0,23 & 3,07 & 0,47 & 5,09 & 2,02 \\
\hline Honduras & 0,19 & 2,58 & 0,36 & 3,93 & 1,35 \\
\hline Índia & 0,29 & 3,89 & 0,35 & 3,77 & $-0,12$ \\
\hline Peru & 0,19 & 2,55 & 0,28 & 3,01 & 0,46 \\
\hline Guatemala & 0,31 & 4,16 & 0,24 & 2,56 & $-1,60$ \\
\hline Uganda & 0,14 & 1,91 & 0,20 & 2,21 & 0,29 \\
\hline Resto do Mundo & 2,24 & 29,88 & 1,46 & 15,84 & $-14,05$ \\
\hline Total & 7,50 & 100,00 & 9,22 & 100,00 & - \\
\hline
\end{tabular}

Nota: Ranking relacionado ao ano de 2016

Fonte: Elaborado pelos autores a partir de FAO (2018).

Com base na Tabela 1, percebe-se que o incremento na produção de café no mundo, nos anos de 2000 a 2016, foi de 22,93\%, passando de 7,50 para 9,22 milhões toneladas. O Brasil e a Indonésia tiveram um aumento de 58,95\% e 16,36\%, respectivamente. No quesito participação de mercado, o Brasil apresentou crescimento em 7,37\% e a Indonésia, redução em 0,46\%. Outros países que também elevaram sua participação de mercado foram Vietnã $(5,14 \%)$, Etiópia 
$(2,02 \%)$, Honduras $(1,35 \%)$, Peru $(0,46 \%)$ e Uganda $(0,29 \%)$. Por outro lado, o país que mais reduziu sua participação de mercado foi a Guatemala, em 1,60\%, correspondendo a um declínio na produção de $22,58 \%$, que passou de 0,31 milhões de toneladas em 2000 a 0,24 milhões de toneladas em 2016, fato ligado à epidemia de ferrugem nas plantações em 2012, quando $20 \%$ das plantações foram perdidas em função da doença, e também pela falta de competitividade do país, que apresenta altos custos de produção (United States Department of Agriculture - USDA, 2018).

A seguir, na Tabela 2, é avaliada a participação dos principais exportadores mundiais de café com base nos mesmos períodos.

Tabela 2 - Participação dos maiores exportadores mundiais de café verde em 2000 e em 2016

\begin{tabular}{|c|c|c|c|c|c|}
\hline \multirow[b]{2}{*}{ País } & \multicolumn{2}{|c|}{2000} & \multicolumn{2}{|c|}{2016} & \multirow[b]{2}{*}{$\begin{array}{c}\text { Variação da } \\
\text { participação } \\
\text { (em p.p.) }\end{array}$} \\
\hline & $\begin{array}{l}\text { Exportação } \\
\text { (milhões de } \\
\text { toneladas) }\end{array}$ & $\begin{array}{c}\text { Participação } \\
(\%)\end{array}$ & $\begin{array}{c}\text { Exportação } \\
\text { (milhões de } \\
\text { toneladas) }\end{array}$ & $\begin{array}{c}\text { Participação } \\
(\%)\end{array}$ & \\
\hline Brasil & 0,97 & 17,59 & 1,82 & 25,46 & 7,88 \\
\hline Vietnã & 0,73 & 13,35 & 1,40 & 19,54 & 6,20 \\
\hline Colômbia & 0,51 & 9,25 & 0,73 & 10,26 & 1,01 \\
\hline Indonésia & 0,34 & 6,14 & 0,41 & 5,76 & $-0,38$ \\
\hline Alemanha & 0,17 & 3,04 & 0,34 & 4,69 & 1,65 \\
\hline Honduras & 0,17 & 3,04 & 0,31 & 4,33 & 1,29 \\
\hline Índia & 0,16 & 2,94 & 0,25 & 3,50 & 0,56 \\
\hline Peru & 0,14 & 2,60 & 0,24 & 3,34 & 0,74 \\
\hline Bélgica & 0,07 & 1,35 & 0,19 & 2,64 & 1,28 \\
\hline Guatemala & 0,29 & 5,30 & 0,18 & 2,51 & $-2,79$ \\
\hline Resto do Mundo & 1,95 & 35,41 & 1,29 & 17,98 & $-17,43$ \\
\hline Total & 5,50 & 100,00 & 7,16 & 100,00 & - \\
\hline
\end{tabular}

Nota: Ranking relacionado ao ano de 2016

Fonte: Elaborado pelos autores a partir de FAO (2018)

O comércio mundial de café é dominado em grande parte pelo Brasil, que, no ano de 2016, teve uma participação de 25,46\% no total exportado, seguido por Vietnã, Colômbia, Indonésia, Alemanha, e Honduras, com, respectivamente, 19,54\%, 10,26\%, 5,76\%, 4,69\% e $4,33 \%$. Neste cenário, novamente a Guatemala foi o país que mais reduziu sua participação de mercado em 2,79\%, correspondendo a um declínio na exportação de 37,93\%, que passou de 0,29 milhões de toneladas em 2000 a 0,18 milhões de toneladas em 2016, sendo a quebra de safra de 2012, os altos custos de produção, e os baixos preços internacionais do café os responsáveis pela queda no comércio exterior do país (USDA, 2018).

Em relação à disponibilidade de café brasileiro, na safra 2016/2017, foi de 3,51 milhões de toneladas, e, destes, 56,52\% foram destinados à exportação, 36,94\%, ao consumo interno e 6,54\% foram os estoques finais (USDA, 2018). Percebe-se a alta participação da exportação que está relacionada à orientação da indústria cafeeira ao mercado externo. 
Além disso, a produção brasileira de café é distribuída pelas regiões do país, tomando como base a safra de 2016, da seguinte forma: $5 \%$ Norte, $8 \%$ Nordeste, $1 \%$ Centro-Oeste, $84 \%$ Sudeste e 2\% Sul de acordo com a Companhia Nacional de Abastecimento (CONAB, 2016). Com base neste levantamento, percebe-se a alta concentração do café produzido pelo país na Região Sudeste. A Figura 2 ilustra a produção e a produtividade do café no Brasil, entre os anos de 2000 a 2016.

Figura 2 - Evolução da produção e da produtividade do café verde no Brasil entre 2000 e 2016

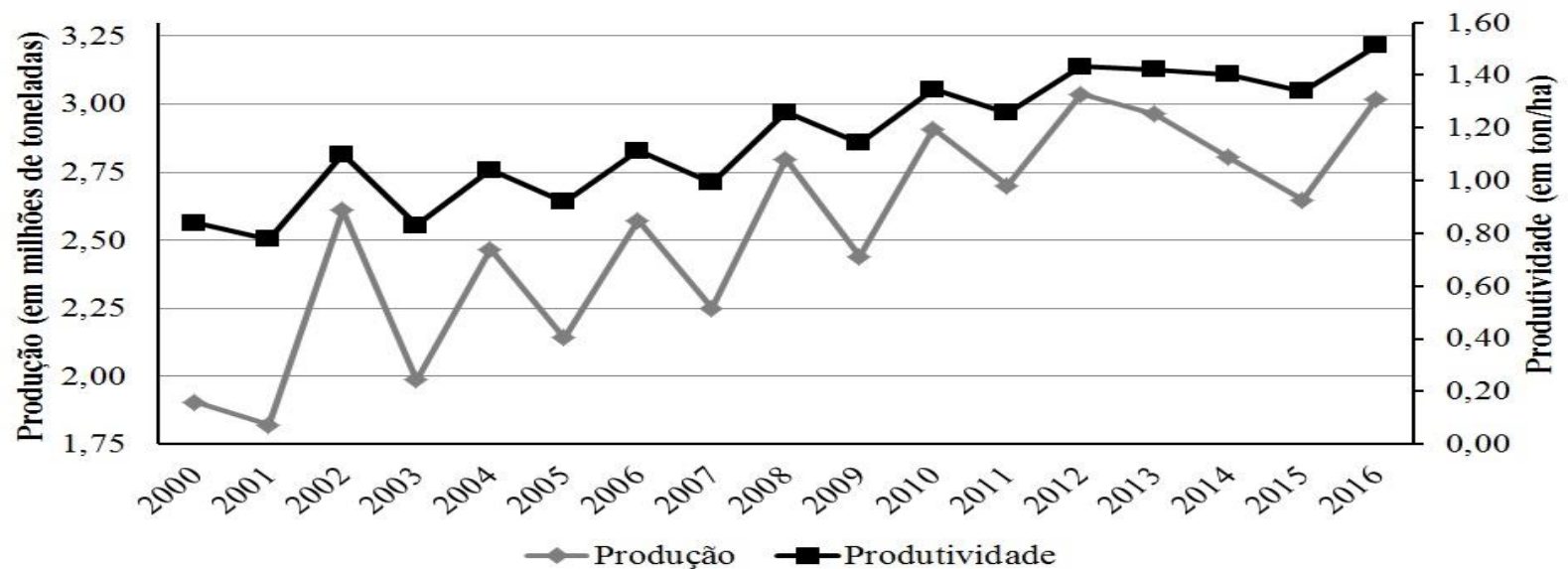

Fonte: Elaborado pelos autores a partir de FAO (2018)

A partir da análise da Figura 2, é possível observar que, apesar da oscilação da série, o crescimento da produtividade do café brasileiro é constante desde o início do período analisado. De acordo com a Conab (2017), o incremento produtivo do café brasileiro está ligado à aplicação de novas tecnologias nessa cultura, com o uso de novas variedades, adubação adequada, irrigação, entre outros. Acrescente-se ainda que a média da produtividade brasileira no período foi de 1,16 ton/ha, bem acima da média mundial de 0,77 ton/ha (FAO, 2018), demonstrando o bom desenvolvimento tecnológico nesta etapa produtiva. A Figura 3 ilustra a importação, a exportação e o saldo comercial de café verde no Brasil, entre os anos de 2000 a 2016.

Figura 3 - Evolução da importação, exportação e saldo comercial do café verde no Brasil entre 2000 e 2016 

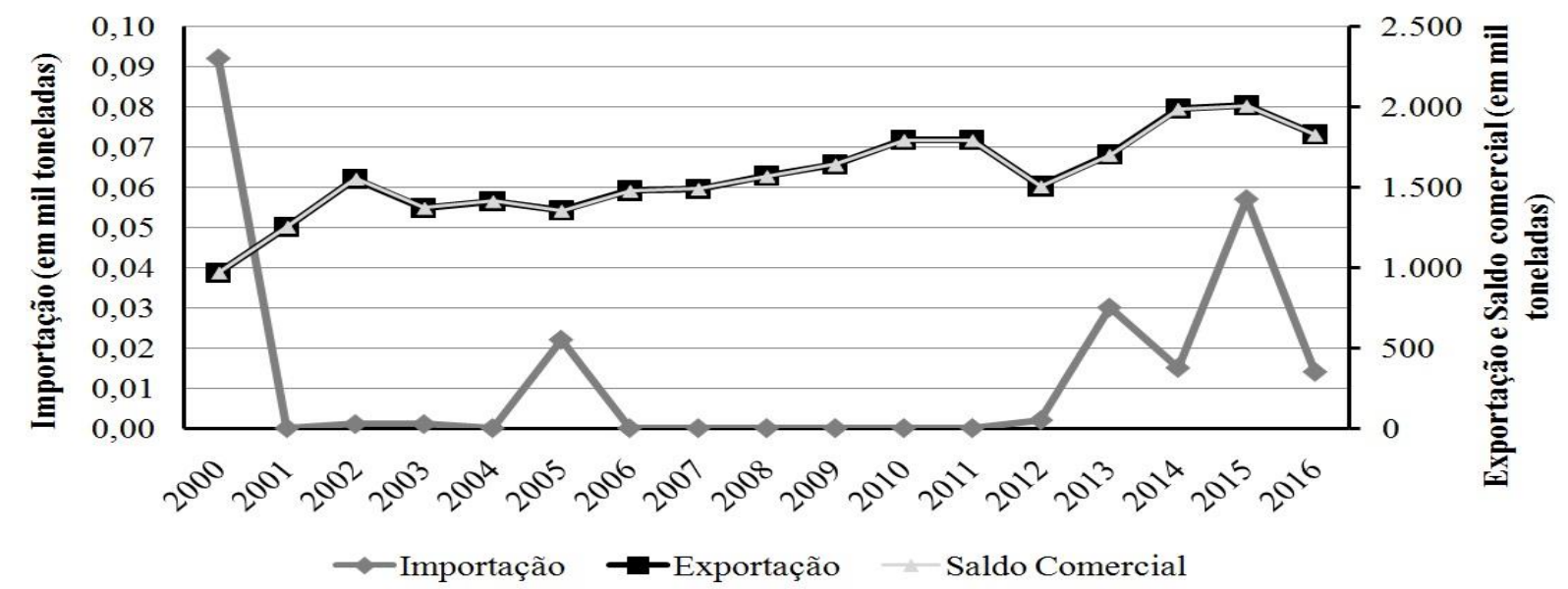

Fonte: Elaborado pelos autores a partir de FAO (2018)

Percebe-se, assim como no caso da produção e da produtividade, uma linha de tendência crescente nas exportações brasileiras de café, com um crescimento de $88,60 \%$ entre os anos de 2000 e 2016 (FAO, 2018). Neste mesmo período, as importações apresentam-se pouco significativas dadas as proporções. A Figura 4 ilustra a produção e a produtividade do café verde na Indonésia, entre os anos de 2000 e 2016.

Figura 4 - Evolução da produção e da produtividade do café verde na Indonésia entre 2000 e 2016

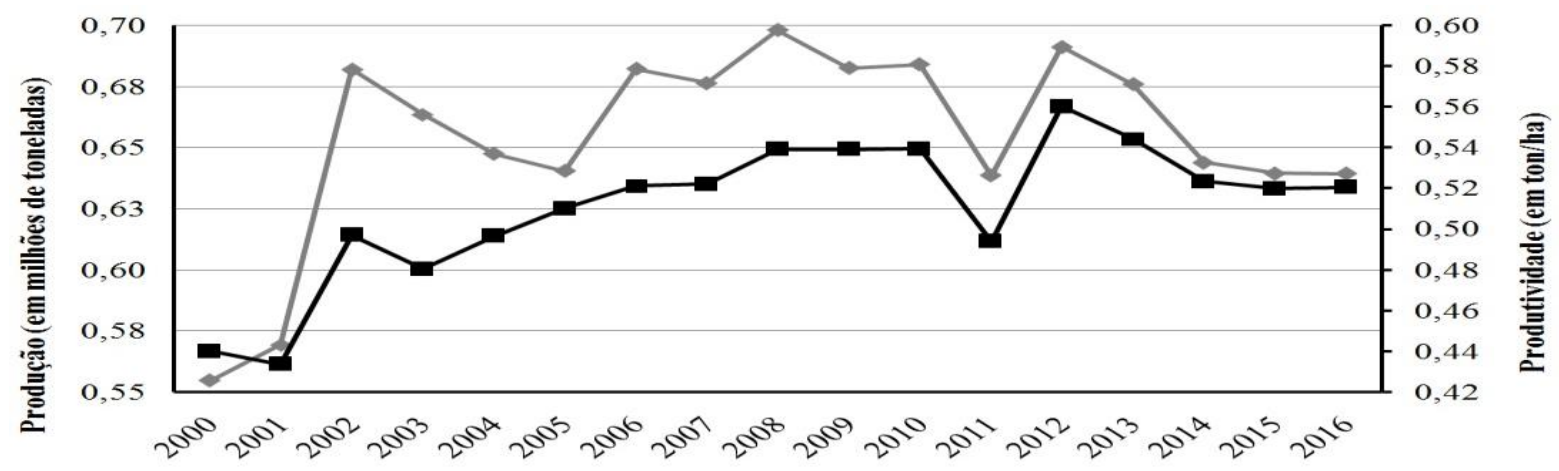

Fonte: Elaborado pelos autores a partir de FAO (2018)

Pela análise da Figura 4, percebe-se o crescimento na produtividade do café na Indonésia, que, no ano de 2000, era de 0,44 ton/ha e passou a 0,52 ton/ha no ano de 2016, com uma média de 0,51 ton/ha. A produção também apresentou tendência crescente, passando de 0,55 milhões de toneladas em 2000 a 0,64 milhões de toneladas em 2016 (FAO, 2018), um incremento de $16,36 \%$, fato impulsionado pelo aumento do consumo doméstico, das condições climáticas favoráveis e aumento da produtividade com a utilização de técnicas de poda e cultivo (USDA, 2014; USDA, 2017).

Segundo o USDA (2019), o total disponível de café na Indonésia, na safra 2016/2017, foi de 0,68 milhões de toneladas, e, destes, $71,77 \%$ foram destinados à exportação, $28,12 \%$ ao 
consumo interno e $0,11 \%$ foram os estoques finais. Percebe-se que a indústria cafeeira indonésia, tal como a brasileira, é orientada ao mercado externo.

Com base na Figura 5, identifica-se a evolução das importações, das exportações e o saldo comercial do café verde da Indonésia. As exportações tiveram um incremento de 22,19\%, passando de 337,60 mil de toneladas em 2000 para 412,53 mil toneladas em 2016. Este crescimento está relacionado principalmente ao incremento da produção (USDA, 2014; USDA, 2017). Já as importações apresentam-se pouco significativas dadas as proporções e serviram principalmente para abastecer o mercado interno (USDA, 2012; USDA, 2016).

Figura 5 - Evolução da importação, exportação e saldo comercial do café verde na Indonésia entre 2000 e 2016
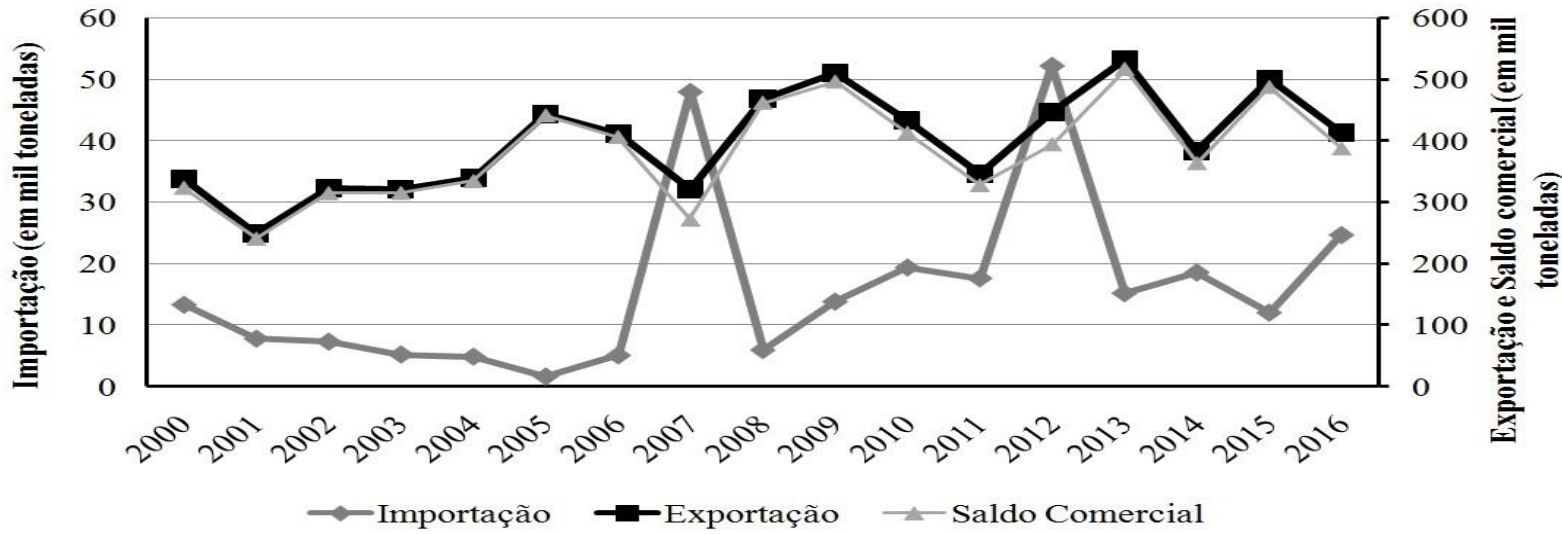

Fonte: Elaborado pelos autores a partir de FAO (2018).

Por fim, na Tabela 3, é apresentada uma síntese dos principais fatores de competitividade do café entre Brasil e Indonésia, nos anos de 2000 e de 2016.

Tabela 3 - Participação do Brasil e da Indonésia no mercado mundial do café

\begin{tabular}{c|ccc|c|c|c|c|c|c}
\hline \multirow{2}{*}{ Países } & \multicolumn{4}{|c|}{ Produção (milhões de toneladas) } & \multicolumn{4}{c}{ Exportação (milhões de toneladas) } \\
\cline { 2 - 10 } & 2000 & $\%$ & 2016 & $\%$ & 2000 & $\%$ & 2016 & $\%$ \\
\hline Brasil & 1,90 & 25,37 & 3,02 & 32,74 & 0,97 & 17,59 & 1,82 & 25,46 \\
Indonésia & 0,55 & 7,39 & 0,64 & 6,93 & 0,34 & 6,14 & 0,41 & 5,76 \\
Demais países & 5,04 & 67,22 & 5,56 & 60,32 & 4,20 & 76,28 & 4,92 & 68,77 \\
Mundo & 7,50 & 100,00 & 9,22 & 100,00 & 5,50 & 100,00 & 7,16 & 100,00 \\
\hline
\end{tabular}

Fonte: Elaborado pelos autores a partir de FAO (2018).

Por meio das análises realizadas, observou-se que o Brasil apresentou expressiva superioridade na produção e na produtividade em relação à Indonésia, ao longo dos últimos anos. Em relação à produção, o país brasileiro apresentou volume quatro vezes maior que o indonésio, e, na produtividade, obteve maior média (1,16 ton/ha), já que a Indonésia apresentou $(0,51$ ton/ha), indicando maior competitividade. 
Brasil e Indonésia possuem semelhança no fato de registrarem níveis de exportação muito superiores aos de importação, sugerindo que os países têm competitividade no mercado internacional do café. Ainda, ambos os países aumentaram o volume exportado no período, indicando expansão e incremento no setor.

\section{Material e métodos}

\subsection{Aspectos metodológicos}

3.1.1 Índices de Vantagem Comparativa Revelada (IVCR) e Vantagem Comparativa Revelada Simétrica (VCRS)

O Índice de Vantagem Comparativa Revelada foi desenvolvido por Balassa (1965), utilizando como base a teoria de Ricardo (1817), como forma de avaliar a competitividade de um país, já que, para o autor, seria inviável avaliar todos os fatores que afetam o desempenho econômico frente aos concorrentes. Além disso, para o autor, esta avaliação deveria recair somente sobre as exportações, uma vez que as importações são influenciadas por barreiras protecionistas. Assim, o IVCR é calculado da seguinte forma:

$$
I V C R=\frac{\frac{x_{i j}}{X_{i}}}{\frac{X_{m j}}{X_{m}}}
$$

em que: $X_{i j}$ representa o total das exportação do país $i$ do produto $j ; X_{i}$ refere-se ao valor total das exportações do país $i ; X_{m j}$ significa o valor total das exportações mundiais do produto $j ; X_{m}$ mostra o valor total das exportações mundiais.

O índice deve ser avaliado da seguinte forma: quando o resultado for superior à unidade, conclui-se que o país possui vantagem comparativa revelada para as exportações de determinado produto. Por outro lado, quando o resultado for menor do que um, o país não possui vantagem comparativa revelada nas exportações de um produto. Além disso, quanto maior for o índice, maior será a vantagem comparativa do país. O IVCR informa o nível das exportações de um país, com relação à sua pauta exportadora, podendo comparar determinado bem entre diferentes países e permitindo revelar o grau de competitividade do país em questão.

A fim de melhor analisar as vantagens comparativas entre mais de um competidor e mais períodos, optou-se por utilizar o Índice de Vantagens Comparativas efetuando a normalização, conforme proposto por Laursen (1998):

$$
V C R S=\frac{I V C R-1}{I V C R+1}
$$


Em que o índice representa a Vantagem Comparativa Revelada Simétrica (VCRS). Assim, o valor do índice passa a variar entre -1 e 1 . Se o índice se encontrar entre -1 e 0 , a economia do estado não possui vantagem comparativa revelada naquele determinado produto; entre 0 e 1, a economia possui vantagem comparativa revelada e, quanto mais próximo de 1 , maior será a vantagem.

\subsubsection{Razão de Concentração (CR)}

No presente estudo, foram selecionados os três principais parceiros comerciais de cada país (no caso, CR3), para o café verde, em 2000 e em 2016, a fim de identificar o grau de concentração da comercialização no mercado internacional, conforme resultados descritos na seção 4.2 .

Para o Brasil, em 2000, os países selecionados foram Alemanha, Estados Unidos e Itália. O total das exportações brasileiras de café verde destinadas a estes países e as representatividades sobre o total de café verde exportado pelo Brasil, em 2000, foram, respectivamente, de US\$268,02 milhões (17,19\%) para a Alemanha; US\$ 218,35 milhões para os Estados Unidos (14,00\%); e US\$ 173,90 milhões para a Itália (11,15\%) (UN COMTRADE, 2018).

Em 2016, para o Brasil, os países selecionados foram novamente Alemanha, Estados Unidos e Itália. O total das exportações brasileiras de café verde e representatividades sobre o total de café verde exportado pelo Brasil, em 2016, foram, respectivamente, de US\$953,58 milhões $(19,69 \%)$ para a Alemanha; US\$ 938,98 milhões para os Estados Unidos (19,39\%); e US\$ 438,75 milhões para a Itália (9,99\%) (UN COMTRADE, 2018).

Para a Indonésia, em 2000, os países selecionados foram Japão, Estados Unidos e Alemanha. O total das exportações indonésias de café verde destinadas a estes países e as representatividades sobre o total de café verde exportado pela Indonésia, em 2000, foram, respectivamente, de US\$ 72,59 milhões $(23,28 \%)$ para o Japão; US\$ 50,98 milhões para os Estados Unidos (16,35\%); e US\$37,30 milhões para a Alemanha (11,96\%) (UN COMTRADE, 2018).

Em 2016, para a Indonésia, os países selecionados foram Estados Unidos, Alemanha e Japão. O total das exportações indonésias de café verde e representatividades sobre o total de café verde exportado pela Indonésia em 2016, foram, respectivamente, de US\$ 269,90 milhões 
(26,97\%) para os Estados Unidos; US\$ 90,19 milhões para a Alemanha (9,01\%); e US\$ 86,50 milhões para o Japão (8,65\%) (UN COMTRADE, 2018).

O somatório das parcelas de mercado das k-ésimas maiores empresas ou países define o grau de concentração, sendo apresentado na Fórmula (3):

$$
C R_{k}=\sum_{i=1}^{k} S i
$$

$\mathrm{Na}$ fórmula, Si: representa a parcela de mercado do i-ésimo país, enquanto $k$ :significa o número de países pesquisados. Quanto mais alto o valor, mais concentrado é o fluxo comercial das $k$ maiores nações.

\subsection{3 Índice de Orientação Regional (IOR)}

O IOR foi proposto por Yeats (1997) e visa mensurar o peso de um setor/produto nas exportações bilaterais em relação ao peso de suas exportações totais com destino ao resto do mundo. Varia de zero até o infinito. Valores maiores que 1 indicam orientação favorável ao comércio bilateral; o IOR igual a 1 sugere que não há preferência de destino para a exportação, ou seja, o produto não possui orientação de comércio. Valores crescentes do IOR ao longo do tempo indicam tendência para exportar mais para determinado país. Assim, o IOR é calculado da seguinte forma:

$$
I O R=\frac{\frac{X_{k i j}}{X_{i j}}}{\frac{X_{k i e j}}{X_{i e j}}}
$$

em que: Xkij representa as exportações da commodity $k$ do país $i$ para o país $j$; Xij refere-se ao total das exportações do país $i$ para o país $j$; Xkiej significa as exportações da commodity $k$ de $i$ para extra $j$; e Xiej mostra o total das exportações do país $i$ para extra $j$.

\subsection{Fontes dos dados}

$\mathrm{Na}$ análise do mercado mundial do café verde e, especialmente, do panorama brasileiro e indonésio, o presente estudo utilizou a base de dados do FAO (Food and Agriculture Organization of the United Nations). Para os principais produtores e exportadores mundiais e, especialmente, o Brasil e a Indonésia, em 2000 e 2016, foram analisadas as variáveis produção 
(em milhões de toneladas), importação (em mil toneladas), exportação (em milhões de toneladas na Tabela 2, e em mil toneladas nas Figuras 3 e 5), e produtividade (em ton/ha), bem como medidas as participações de cada país, em relação à produção e à exportação, no total mundial.

Para os cálculos do VCRS, da CR, e do IOR foram empregados os dados disponíveis no UN COMTRADE (United Nations Comtrade), na FAO (Food and Agriculture Organization of the United Nations) e na WTO (World Trade Organization).

\section{Análise e discussão dos resultados}

\subsection{Vantagens comparativas reveladas e competitividade das exportações do café}

A Figura 6 especifica os dados do VCRS do Brasil e da Indonésia de 2000 a 2016. Durante todo o período, os dois países apresentaram vantagem comparativa relevada simétrica, com índices entre zero e 1 (um). Além disso, os índices apresentaram comportamentos distintos: no Brasil, não houve significativas alterações; e, na Indonésia, houve crescimento no valor, indicando aumento no nível de competitividade, demonstrando que as exportações do país foram superiores às realizadas no mundo. Ainda, o Brasil foi o mais competitivo de 2000 a 2016 , apresentando índices superiores ao concorrente.

Figura 6 - Índice de Vantagem Comparativa Revelada Simétrica do café verde do Brasil e da Indonésia de 2000 a 2016.

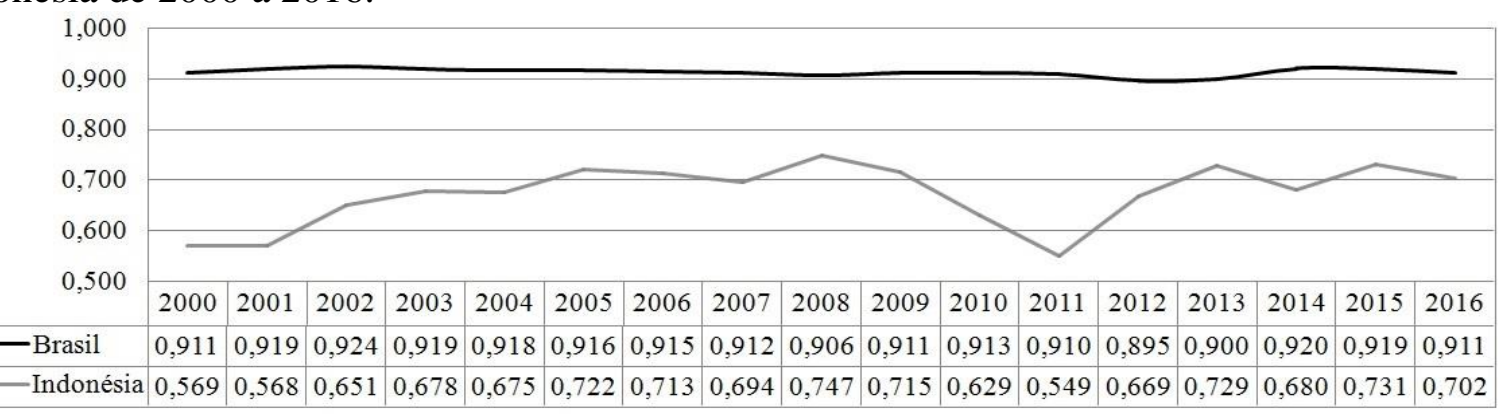

Fonte: Elaborado pelos autores a partir de FAO (2018) e WTO (2018).

A presente pesquisa demonstrou estar em consonância com alguns trabalhos já realizados sobre a competitividade do café brasileiro. Para Sereia, Camara \& Anhesini (2012), que também utilizaram o VCRS como indicador, as exportações de café do Brasil se apresentaram competitivas entre os anos de 1990 a 2007, com índice variando entre 0,89 a 0,93. Segundo Thomé \& Ferreira (2015), as exportações brasileiras de café foram competitivas entre os anos de 2003 a 2012. Outro estudo, como o de Franck et al. (2016), apresentou como resultado competitividade na exportação de café entre 1999 e 2014. Já para Arevalo, Arruda \& Carvalho (2016), o Brasil foi competitivo nas exportações de café verde entre os anos de 1994 a 2013. 


\subsection{Grau de concentração e Índice de Orientação Regional das exportações do café verde}

4.2.1 Grau de concentração e Índice de Orientação Regional das exportações de café verde do Brasil

Na Tabela 4, são apresentados os graus de participação individual e em conjunto (CR3) dos principais países de destino das exportações do café verde do Brasil para os anos de 2000 e 2016. Os resultados revelam aumento na concentração das exportações no período analisado. As possíveis razões desta elevação estão ligadas ao crescimento das exportações brasileiras de café verde à Alemanha, Estados Unidos e Itália de, respectivamente, 256\%, 330\% e 152\%, e a elevação nas participações de mercado, de Alemanha e Estados Unidos, respectivamente, de $17,19 \%$ a $19,69 \%$, e de $14,00 \%$ a $19,39 \%$ (UN CONTRADE, 2018).

Tabela 4 - CR3 das exportações de café verde do Brasil para os anos de 2000 e 2016

\begin{tabular}{c|l|c|c|c}
\hline \multirow{2}{*}{ Produtos/ Anos } & \multicolumn{2}{c}{ 2000 } & \multicolumn{2}{c}{ P016 } \\
\cline { 2 - 6 } & \multicolumn{1}{c}{ Países } & \% & \multicolumn{1}{c}{ Países } & 19,69 \\
\multirow{3}{*}{ Café verde } & Alemanha & 17,19 & Alemanha & 19,39 \\
& Estados Unidos & 14,00 & Estados Unidos & 9,99 \\
\hline & Itália & 11,15 & Itália & \multicolumn{2}{c}{49,07} \\
\hline
\end{tabular}

Fonte: Elaborado pelos autores a partir de UN COMTRADE (2018)

Pela análise da Figura 7, identifica-se orientação das exportações brasileiras de café verde (IOR) aos países que foram seus principais destinos em 2000 e 2016. Somente as exportações para os Estados Unidos, no período de 2000 a 2005, não apresentaram a orientação de mercado; no período de 2006 a 2016, as exportações para Alemanha e Itália, e de 2000 a 2016, apresentaram a orientação de mercado, com IOR superior à unidade. 
Figura 7 - Índice de Orientação Regional (IOR) das exportações brasileiras de café verde para Alemanha, Itália e Estados Unidos, em US\$

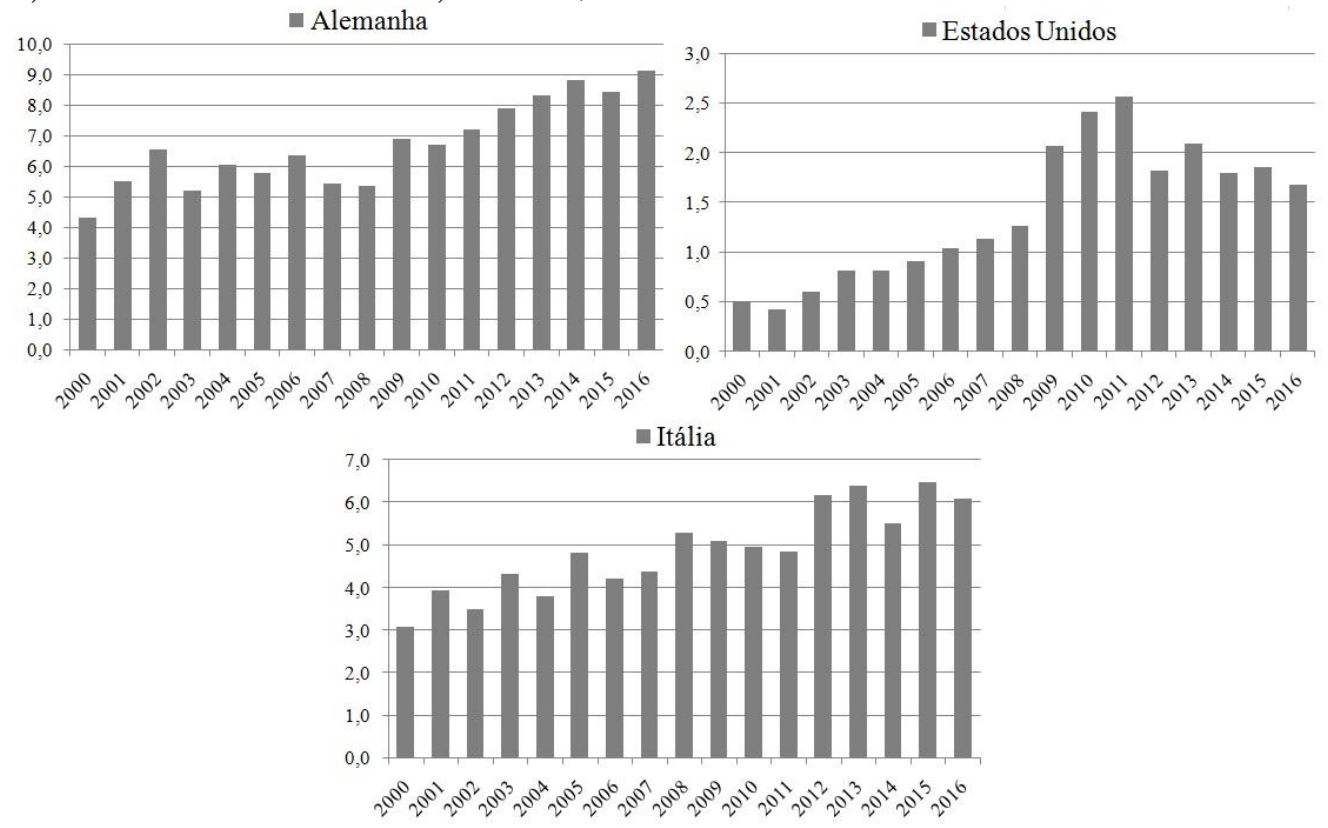

Fonte: Elaborado pelos autores a partir de UN COMTRADE (2018)

Ainda, na Figura 7, verifica-se a evolução do IOR, demonstrando a tendência das exportações brasileiras do café verde aos países parceiros.

As exportações brasileiras do café verde para a Alemanha foram crescentes, passando de US\$ 268,20 milhões, em 2000, a US\$ 953,58 milhões em 2016 (UN COMTRADE, 2018), refletindo, desta forma, as elevações consecutivas do IOR, que passou de 4,32 a 9,10. Destaca-se que o país é um importante parceiro comercial brasileiro, assumindo a $4^{\mathrm{a}}$ e $5^{\mathrm{a}}$ posição, respectivamente, em 2000 e 2016, entre países para os quais o Brasil mais exportou, sendo os principais produtos o minério de ferro, o café e a soja (BRASIL, 2018).

A tendência das exportações brasileiras aos Estados Unidos foi de crescimento, uma vez que, em 2000, eram de US\$ 13,39 bilhões, e, em 2016, foram de US\$23,30 bilhões, com um aumento de 74\%. Nesta mesma medida, houve incremento das importações norte-americanas de café verde do Brasil, que, em 2000, eram de US\$218,35 milhões, e, em 2016, foram de US\$ 938,98 milhões (UN COMTRADE, 2018), com um aumento de 330\%, evidenciado nos valores crescentes do IOR no período, que passou de 0,51 em 2000, a 1,67 em 2016. Ainda, os Estados Unidos apresentam importante parceria comercial com o Brasil, assumindo a $2^{\mathrm{a}}$ e $1^{\mathrm{a}}$ posição, respectivamente, em 2000 e 2016, de países para os quais o Brasil mais exportou, sendo os principais produtos aviões, calçados e produtos semimanufaturados de ferro (BRASIL, 2018).

Em relação à Itália, as importações de café verde do Brasil representaram uma média de $38,32 \%$, de 2000 a 2016, em relação ao total da importação do produto, caracterizando o país brasileiro como o maior fornecedor da commodity no período, seguido por Vietnã e Índia, com as 
médias de participações, respectivamente, de 12,49\% e 10,84\% (UN COMTRADE, 2018). Além disso, os valores do IOR das exportações brasileiras de café verde para a Itália foram crescentes, passando de 3,10, em 2000, a 6,08 em 2016, indicando fortalecimento do comércio e tendência a exportar mais.

4.2.2 Grau de concentração e Índice de Orientação Regional das exportações de café verde da Indonésia

Pela análise da Tabela 5, percebe-se uma redução da concentração das exportações de café verde da Indonésia, de 2000 a 2016, passando de 51,59\% para 44,63\%, o que indica aumento na dispersão das exportações. Como origem da mudança nas importações dos principais parceiros indonésios, como o caso da Alemanha, que, em 2016, teve parcerias comerciais fortalecidas com Brasil, Vietnã e Honduras, os quais, somados, representaram $62 \%$ do total de café verde importado pelo país alemão. Já o Japão teve sua parceria comercial fortalecida com o Brasil com aumento de $10 \%$ na participação das importações brasileiras de café que, em 2000, eram de US\$ 178,19 milhões (representando 23\% das importações japonesas de café verde), e, em 2016, passaram a US\$ 432,03 milhões (representando 33\% das importações japonesas de café verde) (UN COMTRADE, 2018).

Tabela 5 - CR3 das exportações de café verde da Indonésia para os anos de 2000 e 2016

\begin{tabular}{|c|c|c|c|c|}
\hline \multirow{2}{*}{$\begin{array}{c}\text { Produtos/ } \\
\text { Anos }\end{array}$} & \multicolumn{2}{|c|}{2000} & \multicolumn{2}{|c|}{2016} \\
\hline & Países & $\%$ & Países & $\%$ \\
\hline \multirow{3}{*}{ Café verde } & Japão & 23,28 & Estados Unidos & 26,97 \\
\hline & Estados Unidos & 16,35 & Alemanha & 9,01 \\
\hline & Alemanha & 11,96 & Japão & 8,65 \\
\hline CR3 & & & & \\
\hline
\end{tabular}

Fonte: Elaborado pelos autores a partir de UN COMTRADE (2018)

Na Figura 8, verifica-se a evolução do IOR, demonstrando a tendência das exportações indonésias do café verde aos países parceiros.

Figura 8 - Índice de Orientação Regional (IOR) das exportações indonésias de café verde para o Japão, os Estados Unidos, e a Alemanha, em US\$ 

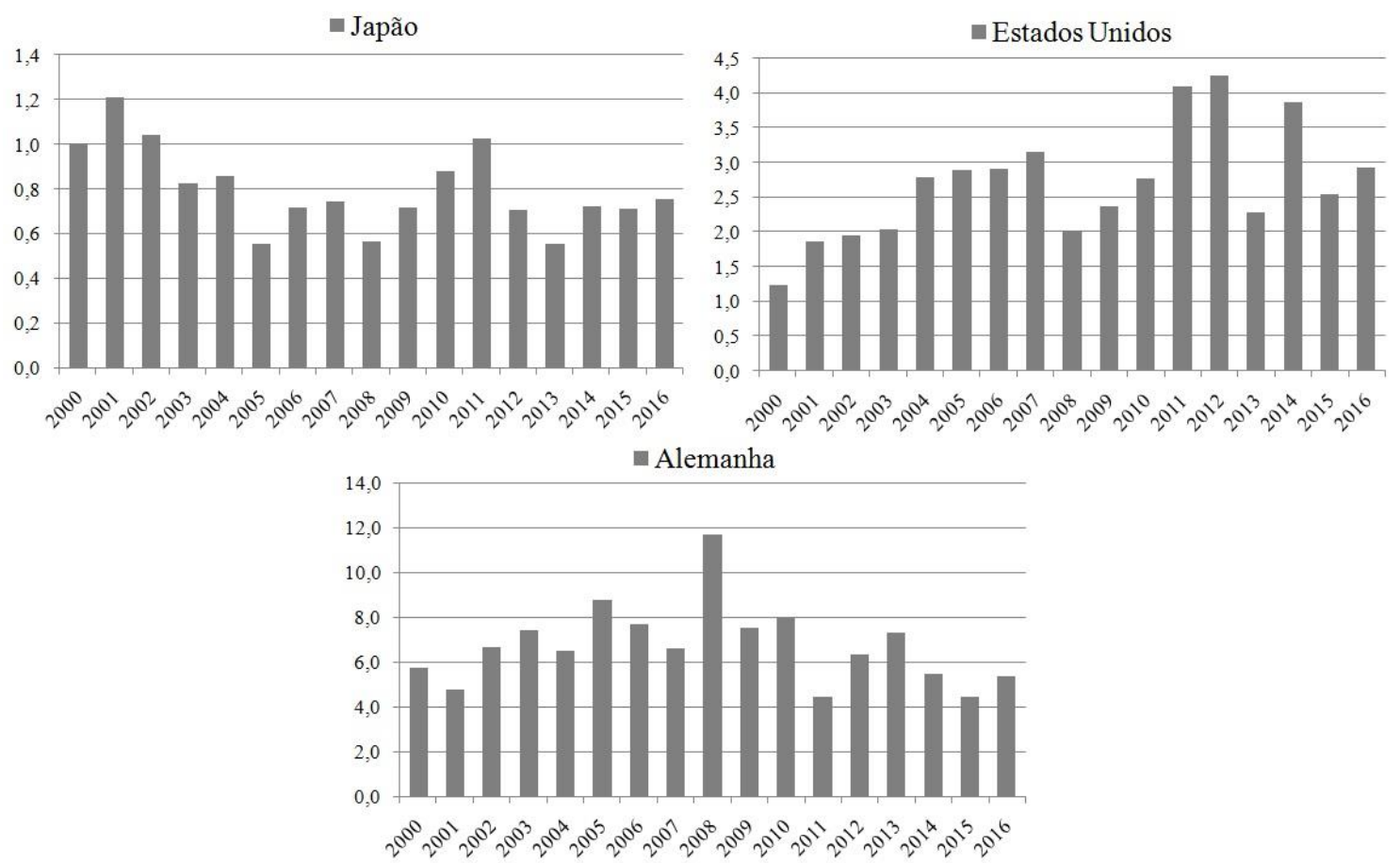

Fonte: Elaborado pelos autores a partir de UN COMTRADE (2018)

A tendência do IOR das exportações indonésias de café verde para o Japão foi de redução, uma vez que, em 2000, era igual à unidade, e, em 2016, passou a 0,75, sendo que, de

2003 a 2010 e de 2012 a 2016, foi inferior à unidade, indicando ausência na orientação de mercado. As exportações de café da Indonésia ao país japonês foram crescentes, já que, em 2000, era de US\$ 72,59 milhões, e, em 2016, passaram a US\$ 86,50 milhões, ou seja, tiveram $19,16 \%$ de incremento, porém, suas representatividades sobre o total exportado da Indonésia ao Japão foram baixas, com uma média, entre os anos de 2003 a 2010 e de 2012 a 2016, de 0,45\% (UN CONTRADE, 2018), explicando, assim, a ausência na orientação de mercado neste período. As exportações totais também cresceram 11,65\%, as quais, em 2000, eram de US\$14,42 bilhões, e, em 2016, passaram a US\$16,10 bilhões, e os principais produtos comercializados, além do café, foram petróleo, carvão, materiais e equipamentos elétricos (INTERNATIONAL TRADE CENTRE - ITC, 2016a).

Em relação aos Estados Unidos, as exportações indonésias de café verde cresceram 429\%, sendo que, em 2000, eram de US\$ 50,98 milhões, e, em 2016, passaram a US\$ 269,90 milhões, e o IOR, de 2000 a 2016, passou de 1,23 a 2,93, respectivamente, indicando orientação nas exportações do produto e tendência a exportar mais. As exportações totais também cresceram 90\%, as quais, em 2000, eram de US\$ 8,49 bilhões, e, em 2016, passaram a US\$ 16,17 bilhões, e os principais produtos comercializados, além do café, foram artigos de vestuário, borracha, calçados, máquinas e equipamentos elétricos (ITC, 2016b). 
As exportações indonésias de café verde para a Alemanha foram crescentes, passando de US\$ 37,30 milhões, em 2000, a US\$ 90,19 milhões em 2016 (UN COMTRADE, 2018), refletindo, desta forma, a orientação de mercado com valores do IOR que passou de 5,71 a 5,33. Além disso, as exportações totais também cresceram 83\%, sendo que, em 2000, eram de US\$1,44 bilhões, e, em 2016, passaram a US\$ 2,64 bilhões, e os principais produtos comercializados, além do café, foram calçados, máquinas e aparelhos mecânicos, artigos de vestuário, borracha, máquinas e aparelhos elétricos (ITC, 2016c).

\section{Conclusões}

O objetivo deste estudo foi o de analisar a competitividade das exportações brasileiras no mercado mundial do café verde, entre 2000 a 2016, em comparação ao quarto maior produtor e exportador mundial, a Indonésia. Além disso, analisaram-se o grau de concentração e a orientação de mercado das exportações desses países. Os resultados obtidos sobre a participação no comércio internacional para os países, analisando os anos de 2000 e 2016, indicaram tendências opostas na produção, com crescimento do Brasil, passando de 25,37\% a 32,74\%, e redução na Indonésia, de 7,39\% a 6,93\%; e na exportação, com crescimento do Brasil, passando de $17,59 \%$ a $25,46 \%$, e redução na Indonésia, de 6,14\% a 5,76\%.

Sobre a produtividade do café, o Brasil apresentou-se como o mais produtivo, com uma média de 1,16 ton/ha em relação à Indonésia, que apresentou uma média de 0,51 ton/ha, sendo mais competitivo neste quesito.

Em relação à competitividade, os VCRS observados para o Brasil e a Indonésia para o produto café verde foram superiores à unidade, entre 2000 a 2016, comprovando a competitividade internacional dos países. Além disso, o Brasil foi mais competitivo durante todo o período de análise, com índices superiores ao concorrente.

O Brasil apresentou aumento na concentração das exportações do café verde no período analisado, relacionado ao incremento da parceria comercial com Alemanha e Estados Unidos, que elevaram suas importações. A Indonésia, por outro lado, revelou desconcentração nas exportações do café verde de 2000 a 2016, passando de 51,59\% a 44,63\%, fato atrelado à perda de mercado para Brasil, Vietnã e Honduras.

As exportações brasileiras do café verde apresentaram-se orientadas (IOR) aos três principais parceiros comerciais, nos seguintes anos: Alemanha e Itália, de 2000 a 2016; e para os Estados Unidos, de 2006 a 2016. Já a Indonésia, apresentou suas exportações do café verde orientadas, nos seguintes anos, aos países Japão, em 2001, 2002 e 2011; Estados Unidos e Alemanha, de 2000 a 2016. 
Entre as limitações do presente trabalho está o fato de os índices utilizados serem estáticos, ou seja, permitem a análise em períodos de tempos específicos, não compreendendo diversas alterações econômicas. Neste sentido, fazem-se pertinentes análises com acuidade, utilizando modelos econométricos, bem como de Equilíbrio Geral de Gerações Sobrepostas, os quais permitem captar a evolução das mudanças econômicas e sociais, na competitividade setorial.

\section{Referências}

AREVAlO, J. L. S.; ARRUDA, D. O.; CARVAlHO, J. P. Competitividade no comércio internacional do café: um estudo comparativo entre Brasil, Colômbia e Peru. Organizações Rurais \& Agroindustriais, Lavras, v. 18, n. 1, p. 62-78, 2016.

BALASSA, B. Trade liberalization and revealed comparative advantage. The Manchester School of Economic and Social Studies, v. 32, p. 99-123, 1965.

BEST, M. H. The New Competition. Institutions of Industrial Restructuring. Harvard University Press, Cambridge, 1990.

BRASIL - Ministério da Indústria, Comércio Exterior e Serviços (MDIC). Balança Comercial. Disponível em: http://www.mdic.gov.br/index.php/comercio-exterior/estatisticas-de-comercioexterior/balanca-comercial-brasileira-acumulado-do-ano?layout=edit\&id=3056. Acesso em: 18 de dez. 2018.

CONAB - Companhia Nacional de Abastecimento. Acompanhamento da safra brasileira. Café. v. 3 - safra 2016. n.4 - Quarto Levantamento | Dezembro 2016. Disponível em: https://www.conab.gov.br/info-agro/safras/cafe/boletim-da-safra-de-cafe. Acesso em: 17 dez. 2018.

CONAB - Companhia Nacional de Abastecimento. A Cultura do Café: análise dos custos de produção e da rentabilidade nos anos-safra 2008 a 2017. Disponível em:http://www.agricultura.gov.br/noticias/lavoura-produtiva-foi-o-principal-fator-de-aumentoda-renda-do-produtor-de-

cafe/copy_of_ConabAculturadoCafAnlisedosCustosdeProduoedaRentabilidadenosanossafra2008 a2017.pdf. Acesso em: 17 dez. 2018.

FAO - Food and Agriculture Organization of the United Nations. Disponível em: http://www.fao.org/faostat/en/\#data. Acesso em 20 jul. 2018.

FRANCK, A. G. S.; SIlVA, M. L.; SILVA, R. A.; CORONEL, D. A. Análise da competitividade do mercado exportador brasileiro de café. Desafio Online, Campo Grande, v.4, n.3, Set./Dez.2016.

GURGEL, A. C. Impactos de políticas comerciais e agrícolas sobre a agropecuária e a agroindústria brasileiras. In: $52^{\circ}$ Congresso Brasileiro de Economia e Sociologia Rural, 2014, Goiânia. Heterogeneidade e suas implicações no Rural, 2014.

ITC - International Trade Centre. Bilateral trade between Indonesia and Japan. 2016a. Disponível em:

https://www.trademap.org/Bilateral_TS.aspx?nvpm=1\%7c360\%7c\%7c392\%7c\%7c85\%7c\%7c \%7c4\%7c1\%7c1\%7c2\%7c2\%7c1\%7c1\%7c1\%7c1 Acesso em: 28 jun. de 2019.

ITC - International Trade Centre. Bilateral trade between Indonesia and United States of America. 
https://www.trademap.org/Bilateral_TS.aspx?nvpm=1\%7c360\%7c\%7c842\%7c\%7cTOTAL\%7c \%7c\%7c2\%7c1\%7c1\%7c2\%7c2\%7c1\%7c1\%7c1\%7c1 Acesso em: 28 jun. de 2019.

ITC - International Trade Centre. Bilateral trade between Indonesia and Germany. 2016c. Disponível

em: https://www.trademap.org/Bilateral_TS.aspx?nvpm=1\%7c360\%7c\%7c276\%7c\%7cTOTAL\%7c $\% 7 \mathrm{c} \% 7 \mathrm{c} 2 \% 7 \mathrm{c} 1 \% 7 \mathrm{c} 1 \% 7 \mathrm{c} 2 \% 7 \mathrm{c} 2 \% 7 \mathrm{c} 1 \% 7 \mathrm{c} 1 \% 7 \mathrm{c} 1 \% 7 \mathrm{c} 1$

Acesso em: 28 jun. de 2019.

KENNEDY, P.L.; HARRISON, R.W. \& PIEDRA, M.A. Analysing Agribusiness Competitiveness: Case of the United States Sugar Industry. International Food and Agribusiness Management Review, 1(2):245-257, Jai Press Inc., 1998.

LAURSEN K. Revealed comparative advantage and the alternatives as measures of international specialisation. DRUID Working Paper 98-30, 1998.

NISHIJIMA, M.; SAES, M. S. M.; POSTALI, F. A. S. Análise de Concorrência no Mercado Mundial de Café Verde. Revista de Economia e Sociologia Rural - RESR, Piracicaba-SP, Vol. 50, No 1, p. 069-082, Jan/Mar 2012.

PORTER, M. Vantagem Competitiva das Nações. Editora Campus. Rio de Janeiro, 1989.

RICARDO, D. Princípios de Economia Política e Tributação. São Paulo: Editora Nova Cultural, 1996.

SEREIA, V. J.; CAMARA, M. R. G.; ANHESINI, J. A. R. Competitividade do complexo cafeeiro: uma análise a partir do market share e das vantagens comparativas simétricas. Revista de Economia, Editora UFPR, Curitiba, v. 38, n. 1 (ano 36), p. 07-34, jan./abr. 2012.

THOMÉ, K. M.; \& FERREIRA, L. S. Competitividade e estrutura de mercado internacional de café: análise de 2003 a 2012. Coffee Science, Lavras, v. 10, n. 2, p. 184 - 194, abr./jun. 2015.

UN COMTRADE - United Nations Commodity Trade Statistics. Disponível em: http://comtrade.un.org/. Acesso em: 22 ago. 2018.

USDA - United States Department of Agriculture. Custom Query. Disponível em: https://apps.fas.usda.gov/psdonline/app/index.html\#/app/advQuery. Acesso em: 03 jan. 2019.

USDA - United States Department of Agriculture. Coffee annual. Guatemala. 2018. Disponível

em:

https://gain.fas.usda.gov/Recent\%20GAIN\%20Publications/Coffee\%20Annual_Guatemala\%20 City_Guatemala_5-9-2018.pdf. Acesso em 14 dez. 2018.

USDA - United States Department of Agriculture. Coffee semi-annual. Indonesia. December 2014.

Disponível

em:

https://gain.fas.usda.gov/Recent\%20GAIN\%20Publications/Coffee\%20Semi-

annual_Jakarta_Indonesia_11-12-2014.pdf Acesso em 25 jun. 2019.

USDA - United States Department of Agriculture. Coffee annual. Indonesia. 2017. Disponível em:

https://gain.fas.usda.gov/Recent\%20GAIN\%20Publications/Coffee\%20Annual_Jakarta_Indonesi a_5-15-2017.pdf

Acesso em 25 jun. 2019.

VIEIRA FILHO, J. E. R.; \& FISHLOW, A. Agricultura e Indústria no Brasil: Inovação e competitividade. Brasília: Ipea, 2017. 
WTO - World Trade Organization. World Trade Statistical Review. 2017. Disponível em:https://www.wto.org/english/res_e/statis_e/wts2017_e/wts17_toc_e.htm. Acesso em: 20 dez. 2018

WTO - World Trade Organization. 2018. Disponível em: http://stat.wto.org/StatisticalProgram/WSDBStatProgramHome.aspx?Language=E Acesso em: 15 jul. 2018.

WTO - World Trade Organization. Tariff Analysis Online. Disponível em: http://tao.wto.org/ Acesso em: 05 jun. 2019.

YEATS, A. Does Mercosur's trade performance raice concerns about the effects of regional trade arrangements? Washington, D.C.: World Bank, 1997. 33 p. (Policy Research Working Paper, 1729).

Recebido em 02/06/2019 - Aprovado em 25/07/2019. 